(c) American Dairy Science Association, 2005.

\title{
Nutrient Digestibility of Diets with Different Fiber to Starch Ratios when Fed to Lactating Dairy Cows*
}

\author{
J. L. Beckmant and W. P. Weiss \\ Department of Animal Sciences, Ohio Agricultural Research and Development Center \\ The Ohio State University, Wooster 44691
}

\begin{abstract}
The objective of this experiment was to determine whether increasing the dietary neutral detergent fiber (NDF):starch ratio affected NDF digestibility when diets were formulated to have equal in situ NDF digestibility. Six lactating Holstein cows were fed 1 of 3 diets in a replicated $3 \times 3$ Latin square. All diets had $41.5 \%$ of the dry matter $(\mathrm{DM})$ as corn silage but the concentration of corn grain varied from 23.3 to $34.8 \%$ and the NDF:starch ratios were $0.74,0.95$, and 1.27. As corn grain increased, the concentration of a mixture of $54 \%$ soyhulls and $46 \%$ cottonseed hulls decreased. The soyhull:cottonseed hull mixture had the same in situ NDF digestibility as the corn silage. All diets had $18 \%$ forage NDF but starch concentration varied from 25.4 to $33.3 \%$ and NDF varied from 24.7 to $32.2 \%$. Intake tended to increase as the NDF:starch ratio increased. Total tract digestibility (measured by total collection of feces and urine) of dry matter and energy decreased linearly as the NDF:starch ratio increased, but NDF digestibility was not affected by treatment. Retention of $\mathrm{N}$ increased linearly as the NDF:starch ratio increased. As dietary NDF:starch ratio increased, ruminal $\mathrm{pH}$ was not affected, but the concentration of total volatile fatty acids (VFA) decreased and the VFA profile was altered by diet. Consistent with the observed changes in ruminal VFA, milk fat percentage increased with increasing dietary NDF:starch. Intake of digestible energy and output of energy in milk and body weight change was not affected by treatment.
\end{abstract}

(Key words: cottonseed hulls, soyhulls, fiber digestibility)

Abbreviation key: DE = digestible energy; ISNDFD = in situ NDF digestibility; LCFA = long-chain fatty acids.

\footnotetext{
Received August 20, 2004.

Accepted November 19, 2004.

Corresponding author: William P. Weiss; e-mail: weiss.6@osu.edu.

*Salaries and research support provided by state and federal funds appropriated to the Ohio Agricultural Research and Development Center, The Ohio State University. Manuscript No. 24-04AS.

$\dagger$ Present address: Cornell Cooperative Extension-Lewis County, Lowville, NY 13367.
}

\section{INTRODUCTION}

Starchy feedstuffs are substituted for fibrous feedstuffs in diets fed to lactating dairy cows to increase energy intake. When the concentration of NDF in diets is reduced by replacing forages with grain (i.e., starch), DMI of lactating cows usually increases (Allen, 2000). On average, the apparent digestibility of starch is almost twice as high as that of NDF when fed to lactating dairy cows (Firkins et al., 2001), which should increase the digestible energy (DE) concentrations of diets. However, increases in $\mathrm{DE}$ or total digestible nutrient concentrations are often less than expected when starch-based concentrates replace forages (Llano and DePeters, 1985; Weiss and Shockey, 1991).

When starchy concentrates replace forages in diets, total tract digestibility of fiber (NDF, crude fiber, or $\mathrm{ADF}$ ) is often reduced (Putnam and Loosli, 1959; Tyrrell and Moe, 1972; Valadares et al., 2000). However, results from such studies are often, but not always, confounded by increased DMI by cows fed the lower forage diets. Increased DMI can also reduce fiber digestibility (Tyrrell and Moe, 1975; Colucci et al., 1989; Tine et al., 2001). Total tract digestibility of dietary NDF is often reduced when starchy feeds replace fibrous byproducts such as soyhulls (Ipharraguerre and Clark, 2003). Results from the studies collated by Ipharraguerre and Clark (2003) are confounded by changes in source of NDF. The NDF in soyhulls is highly digestible in vitro and in situ (Ipharraguerre and Clark, 2003), and as soyhulls are replaced by starch-based feeds, the proportion of total NDF from soyhulls is reduced.

When starchy feeds replace fibrous feeds, the concentration of NDF is reduced and the concentration of starch increases. The almost complete confounding of $\mathrm{NDF}$ and starch concentrations makes ascribing changes in a response variable to a change in the concentration of specific carbohydrate fractions impossible, as discussed by Armentano and Pereira (1997). Therefore, treatment effects in this experiment are related to changes in NDF to starch ratio, rather than changes in either NDF or starch concentrations. We hypothesized that when the confounding effects of DMI and differences in the inherent digestibility of NDF from 
different sources are reduced, NDF digestibility is less sensitive to decreases in the NDF to starch ratio. The objective of this experiment was to evaluate the effects of changing NDF to starch ratios on nutrient digestibility by lactating cows when those confounding effects were reduced.

\section{MATERIALS AND METHODS}

\section{Cows and Diets}

Six rumen cannulated Holstein cows that averaged 155 DIM (range: 98 to 195) at the start of the experiment were blocked by BW and randomly assigned to a treatment sequence in two $3 \times 3$ Latin squares with 21 $\mathrm{d}$ periods. Initial BW of cows in squares 1 and 2 averaged $587 \mathrm{~kg}( \pm 13 \mathrm{~kg})$ and $633 \mathrm{~kg}( \pm 27 \mathrm{~kg})$, respectively. Cows were housed in individual tie stalls, fed once daily, and milked twice daily. Diets were fed as TMR for approximately 5\% refusal. Milk weights were recorded electronically at each milking. Amount of feed offered and refused was measured daily. Cows were weighed on $\mathrm{d} 3$ and 21 of each period and change in BW was calculated as the difference between these weights. During the last week of each period, digestibility was measured by total collection of urine and feces for $4 \mathrm{~d}$ (Weiss and Wyatt, 2000). Urine (pH kept $<5.0$ with $50 \%$ sulfuric acid) was collected separately from feces using an externally attached urine cup.

Before diets were formulated, 30-h in situ NDF digestibility (ISNDFD) of corn silage, cottonseed hulls, and soyhulls was measured using 2 cows fed a TMR containing $27 \%$ alfalfa silage, $28 \%$ corn silage, and $45 \%$ corn-based concentrate (method described below). The ISNDFD was $43.4 \%(\mathrm{SD}=3.8)$ for corn silage, $18.9 \%$ $(\mathrm{SD}=7.1)$ for cottonseed hulls, and $65.2 \%(\mathrm{SD}=4.2)$ for soyhulls. A mix of $46 \%$ cottonseed hulls and $54 \%$ soyhulls had the same calculated ISNDFD as the corn silage. A diet that contained an excessive concentration of NFC and inadequate concentrations of NDF and forage NDF based on NRC (2001) recommendations was formulated. This diet was designed to promote rumen conditions that would reduce NDF digestibility. Two other diets were formulated to contain the same concentration of forage NDF but with the concentrations of starch and NFC reduced, and that of NDF increased by replacing corn grain with the by-product mix to keep the calculated ISNDFD of all diets equal (Tables 1 and 2).

\section{Sampling and Analyses}

Milk samples (a.m. and p.m.) were taken once each week and analyzed for fat and true protein per approved procedures (AOAC, 1990) with a B2000 Infrared Ana-
Table 1. Ingredient composition of TMR (\% of DM).

\begin{tabular}{|c|c|c|c|}
\hline & \multicolumn{3}{|c|}{ Diets (NDF:starch ratios) ${ }^{1}$} \\
\hline & 0.74 & 0.95 & 1.27 \\
\hline Corn silage & 41.50 & 41.50 & 41.50 \\
\hline Ground corn & 34.80 & 29.05 & 23.30 \\
\hline Soybean meal, $44 \% \mathrm{CP}$ & 20.70 & 20.90 & 21.10 \\
\hline Soybean hulls & $\ldots$ & 3.00 & 5.97 \\
\hline Cottonseed hulls & $\ldots$ & 2.64 & 5.27 \\
\hline Animal/vegetable fat blend & 0.58 & 0.58 & 0.58 \\
\hline Limestone & 1.37 & 1.28 & 1.23 \\
\hline Trace mineral salt & 0.41 & 0.41 & 0.41 \\
\hline Dynamate $^{2}$ & 0.23 & 0.23 & 0.23 \\
\hline Selenium premix, $200 \mathrm{mg} / \mathrm{kg}$ & 0.18 & 0.18 & 0.18 \\
\hline Dicalcium phosphate & 0.12 & 0.12 & 0.12 \\
\hline Mineral/vitamin premix ${ }^{3}$ & 0.11 & 0.11 & 0.11 \\
\hline
\end{tabular}

${ }^{1}$ The NDF:starch ratio was altered by replacing corn grain with increasing amounts of a mixture of 54\% soyhulls and $46 \%$ cottonseed hulls.

${ }^{2}$ IMC Global, Lake Forest, IL.

${ }^{3}$ Contained $3.2 \%$ zinc oxide, $1.6 \%$ copper sulfate, $10.6 \%$ Vitamin A premix $(30,000 \mathrm{IU} / \mathrm{g}), 37.0 \%$ Vitamin D premix $(3,000 \mathrm{IU} / \mathrm{g})$, and $47.6 \%$ Vitamin E premix (44 IU/g).

lyzer (Bentley Instruments, Chaska, MN) and for MUN (Skalar SAN Plus segmented flow analyzer, Skalar Inc., Norcross, GA) by DHI Cooperative Inc., Columbus, OH. At the end of each period, rumen fluid was sampled via cannulas ( 6 to 8 handfuls of rumen contents from sites throughout the rumen) immediately before feeding (0 h) and at 3, 6, and $9 \mathrm{~h}$ after feeding. The $\mathrm{pH}$ was measured and samples were acidified with $10 \mathrm{~N}$ phosphoric acid, and frozen $\left(-20^{\circ} \mathrm{C}\right)$ until analyzed for VFA by GLC. Silage samples were taken weekly and analyzed for DM by oven drying $\left(24 \mathrm{~h}\right.$ at $\left.100^{\circ} \mathrm{C}\right)$ to adjust diets for changes in DM. During the digestion trials, silages, concentrates, feces, and orts (both within a cow) were sampled daily and composited by period. Samples (except for concentrates) were lyophilized and all samples were ground through a 1-mm screen (Wiley Mill, Arthur A. Thomas, Philadelphia, PA). Ground samples were analyzed for $\mathrm{DM}\left(100^{\circ} \mathrm{C}\right.$ oven for $\left.24 \mathrm{~h}\right), \mathrm{NDF}\left(\right.$ Ankom $^{200}$ Fiber Analyzer, ANKOM Technology, Fairport, NY) with sodium sulfite and amylase (Sigma A3306, Sigma Diagnostics, St. Louis, MO), and ash, CP (Kjeldahl N $\times$ 6.25), and ADF (AOAC, 1990), sulfuric acid lignin (Robertson and Van Soest, 1981), energy (Oxygen Bomb Calorimeter model 1281, Parr Instruments, Moline, IL), and long-chain fatty acids (LCFA) and starch (Weiss and Wyatt, 2000). To reduce loss of volatile $\mathrm{N}$, undried feces were assayed for CP. The concentration of NFC was calculated as $100-(\mathrm{NDF}+\mathrm{ash}+\mathrm{CP}+\mathrm{LCFA}+$ $1)$. In that equation, the term $(\mathrm{LCFA}+1)$ was used as an estimate of ether extract (Allen, 2000). Daily milk and urine samples taken during the collection period were composited within cow and analyzed for $\mathrm{N}$ via the Kjeldahl method (AOAC, 1990). 
Table 2. Composition data for selected ingredients and TMR.

\begin{tabular}{|c|c|c|c|c|c|c|}
\hline \multirow[b]{2}{*}{ Item $^{1}$} & \multirow{2}{*}{$\begin{array}{l}\text { Corn } \\
\text { silage }\end{array}$} & \multirow{2}{*}{$\begin{array}{l}\text { Cottonseed } \\
\text { hulls }\end{array}$} & \multirow{2}{*}{$\begin{array}{l}\text { Soy } \\
\text { hulls }\end{array}$} & \multicolumn{3}{|c|}{ Diets (NDF:starch) ${ }^{2}$} \\
\hline & & & & Low & Medium & High \\
\hline DM, \% as fed & 35.1 & 89.5 & 91.3 & 65.1 & 65.6 & 67.3 \\
\hline Ash, \% & 4.5 & 2.7 & 5.0 & 5.5 & 5.8 & 5.6 \\
\hline $\mathrm{CP}, \%$ & 7.6 & 6.1 & 14.9 & 16.8 & 17.3 & 17.4 \\
\hline $\mathrm{NDF}, \%$ & 43.8 & 87.8 & 60.6 & 24.7 & 28.6 & 32.2 \\
\hline $30-\mathrm{h}$ in situ NDFD, \% & 43.4 & 18.9 & 65.2 & ND & ND & ND \\
\hline $\mathrm{ADF}, \%$ & 25.8 & 66.4 & 45.5 & ND & ND & ND \\
\hline Lignin, \% & 2.13 & 22.4 & 1.47 & ND & $\mathrm{ND}$ & ND \\
\hline Forage NDF, \% & & & & 18.2 & 18.2 & 18.2 \\
\hline Starch, \% & 22.1 & ND & ND & 33.3 & 30.1 & 25.4 \\
\hline NFC, $\%$ & 40.4 & ND & ND & 48.3 & 43.7 & 40.4 \\
\hline LCFA, \% & 2.7 & ND & ND & 3.7 & 3.6 & 3.4 \\
\hline GE, Mcal/kg & 4.48 & ND & ND & 4.42 & 4.42 & 4.40 \\
\hline $\mathrm{Ca}, \%$ & 0.24 & ND & ND & 0.93 & 0.87 & 0.86 \\
\hline $\mathrm{P}, \%$ & 0.19 & ND & ND & 0.34 & 0.32 & 0.31 \\
\hline $\mathrm{Mg}, \%$ & 0.16 & ND & ND & 0.20 & 0.21 & 0.21 \\
\hline $\mathrm{K}, \%$ & 1.39 & ND & ND & 1.24 & 1.28 & 1.33 \\
\hline
\end{tabular}

${ }^{1}$ NDFD = NDF Digestibility measured before the experiment using cows not fed experimental diets; LCFA = long-chain fatty acids; GE = gross energy.

${ }^{2}$ The NDF:starch ratio was altered by replacing corn grain with increasing amounts of a mixture of $54 \%$ soyhulls and $46 \%$ cottonseed hulls.

Additional corn silage and concentrate samples were collected and composited for $3 \mathrm{~d}$ before each collection period for ISNDFD measurement. Triplicate dried ground (Wiley Mill, 1-mm screen) corn silage, concentrate, and TMR (made from dried ground samples) samples $(4 \mathrm{~g})$ were placed into Dacron bags $(10 \times 20 \mathrm{~cm}$; pore size, $50 \mu \mathrm{m}$; ANKOM Technology) and inserted into the rumen approximately $2 \mathrm{~h}$ after feeding and incubated for $30 \mathrm{~h}$. The concentrates and TMR were incubated only in cows fed that particular concentrate and TMR. The incubation was conducted concurrently with the total collection period. After removal, bags were washed in tepid water until rinse water was clear, dried overnight at $60^{\circ} \mathrm{C}$, and the residue was analyzed for NDF.

Apparent digestibility of nutrients was calculated as intake of nutrient ( $\mathrm{kg}$ or Mcal/d) minus fecal excretion of nutrient ( $\mathrm{kg}$ or Mcal/d) divided by intake. The concentration of $\mathrm{DE}$ in the diet was calculated by multiplying the gross energy of the diet by energy digestibility. Dietary concentrations of $\mathrm{NE}_{\mathrm{L}}$ and $\mathrm{DE}$, and $\mathrm{NE}_{\mathrm{L}}$ use were estimated (NRC, 2001) using individual cow data, actual feed composition, and NRC-calculated fiber digestibility. The DE of the TMR was also estimated (NRC, 2001) using the measured ISNDFD of corn silage, cottonseed hulls, and soyhulls.

\section{Statistical Analyses}

The experimental design was a replicated $3 \times 3$ Latin square. Mean (by cow) milk production, milk composition, and DMI were calculated from data collected dur- ing the last 2 wk of each period. Production, BW (end of each period), BW change, and digestibility data were analyzed using PROC MIXED (SAS Institute, 1999). The final model included square (fixed, $1 \mathrm{df}$ ), cow within square (random, $4 \mathrm{df}$ ), period (random, $2 \mathrm{df}$ ), diet (fixed, $2 \mathrm{df}$ ), and error ( $8 \mathrm{df}$ ). The original model included square $\times$ diet interaction but this was not significant $(P>0.20)$ for any variable and was pooled with the error term in the final model. Diet effect (i.e., NDF to starch ratio) was partitioned into linear and quadratic contrasts (adjusted for unequal spacing of treatments). The VFA and $\mathrm{pH}$ data were analyzed using the same model except that sampling time (fixed, repeated measure, $3 \mathrm{df}$ ) and the time $\times$ diet interaction ( $6 \mathrm{df}$ ) were added to the model and the error term had 53 degrees of freedom. The error structure used was compound symmetry because it resulted in the lowest Bayesian information criteria.

The method for obtaining DE concentrations (i.e., measured vs. estimated using NRC with calculated NDF digestibilities and measured vs. NRC using ISNDFD) and estimated $\mathrm{NE}_{\mathrm{L}}$ use vs. estimated $\mathrm{NE}_{\mathrm{L}}$ intake were compared using Proc MIXED with a model for a Latin square with a split-plot arrangement of treatments (diet was the whole plot factor and method was the split plot factor). The model included square (fixed, $1 \mathrm{df}$ ), cow within square (random, $4 \mathrm{df}$ ), period (random, $2 \mathrm{df}$ ), diet (fixed, $2 \mathrm{df}$ ), whole plot error (6 df), method (fixed, $1 \mathrm{df}$ ), square $\times$ method (fixed, $1 \mathrm{df}$ ), square $\times \operatorname{diet}$ (fixed, $2 \mathrm{df}$ ), method $\times \operatorname{diet}$ (fixed, $2 \mathrm{df}$ ), square $\times$ diet $\times$ method (fixed, $2 \mathrm{df}$ ), and split-plot error (12 df). 
Table 3. Manure production and digestibility of nutrients in diets with different NDF:starch ratios.

\begin{tabular}{|c|c|c|c|c|c|c|}
\hline & \multicolumn{3}{|c|}{ Diets (NDF:starch) $)^{1}$} & \multirow[b]{2}{*}{ SEM } & \multicolumn{2}{|c|}{$P$ value $^{2}$} \\
\hline & 0.74 & 0.95 & 1.27 & & Linear & Quadratic \\
\hline $\mathrm{DMI},{ }^{3} \mathrm{~kg} / \mathrm{d}$ & 19.9 & 20.6 & 21.4 & 0.9 & 0.13 & NS \\
\hline Wet feces, $\mathrm{kg} / \mathrm{d}$ & 39.4 & 43.2 & 45.3 & 2.3 & 0.05 & NS \\
\hline Urine, $\mathrm{kg} / \mathrm{d}$ & 15.2 & 16.0 & 17.1 & 1.4 & 0.06 & NS \\
\hline Manure, $\mathrm{kg} / \mathrm{d}$ & 54.6 & 59.2 & 62.5 & 3.5 & 0.02 & NS \\
\hline \multicolumn{7}{|c|}{ Digestibility coefficients } \\
\hline DM, \% & 71.2 & 69.9 & 69.1 & 1.5 & 0.02 & NS \\
\hline $\mathrm{OM}, \%$ & 72.2 & 70.8 & 70.1 & 1.4 & 0.01 & NS \\
\hline $\mathrm{N}, \%$ & 71.1 & 69.3 & 70.5 & 1.3 & NS & NS \\
\hline NDF, \% & 45.3 & 46.4 & 46.4 & 3.7 & NS & NS \\
\hline Starch, \% & 90.1 & 89.9 & 91.6 & 1.1 & 0.05 & NS \\
\hline $\mathrm{LCFA},{ }^{4} \%$ & 78.8 & 75.7 & 79.6 & 1.7 & NS & 0.08 \\
\hline Energy, \% & 71.1 & 69.6 & 69.1 & 1.2 & 0.04 & NS \\
\hline
\end{tabular}

${ }^{1}$ The NDF:starch ratio was altered by replacing corn grain with increasing amounts of a mixture of $54 \%$ soyhulls and $46 \%$ cottonseed hulls.

${ }^{2} \mathrm{NS}=P>0.20$.

${ }^{3} \mathrm{DMI}$ measured during the 4-d total collection period.

${ }^{4} \mathrm{LCFA}=$ Long-chain fatty acids.

\section{RESULTS AND DISCUSSION}

\section{Nutrient Digestibility}

Intake during the collection period was not affected by diet and averaged $20.6 \mathrm{~kg} / \mathrm{d}$ (Table 3). Excretion of wet feces, urine, and total manure increased linearly as the NDF:starch ratio increased. The increased excretion of feces was probably caused by reduced DM digestibility, and the increased urine excretion was probably caused by increased intake of $\mathrm{K}$ and possibly $\mathrm{N}$ (Weiss, 2004). The concentration of $K$ in diets increased (Table 2 ) as the NDF:starch ratio increased because soyhulls and cottonseed hulls have higher concentrations of $\mathrm{K}$ than does corn (NRC, 2001). Cows fed the high NDF:starch diet consumed $50 \mathrm{~g} / \mathrm{d}$ more $\mathrm{K}$ than cows on the low NDF:starch diet. Based on an equation by Bannink et al. (1999), this would be expected to increase urine excretion by about $2 \mathrm{~kg} / \mathrm{d}$, which is similar to what was observed.

Digestibility of DM $(P<0.02), \mathrm{OM}(P<0.01)$, and energy $(P<0.04)$ decreased linearly, and digestibility of starch increased linearly $(P<0.05)$ as the NDF:starch ratio increased. Dietary NDF:starch had an unexpected quadratic effect $(P<0.08)$ on digestibility of LCFA (lowest for the intermediate NDF:starch diet). The biological cause for this effect, if any, is unclear. The digestibility of $\mathrm{N}$ and NDF were not affected by diet. The linear decrease in digestibility of $\mathrm{DM}, \mathrm{OM}$, and energy as the NDF:starch ratio increased was caused mostly by the replacement of a highly digestible carbohydrate (starch, average digestibility $90.5 \%$ ) with a less digestible carbohydrate (NDF, average digestibility $45.7 \%$ ). The average digestibility of NDF and starch in this experiment were essentially the same as the average values calcu- lated from a data set of 77 treatment means (Firkins et al., 2001). Starch digestibility increased linearly as the NDF:starch ratio increased, however numerical differences among treatments were quite small $(90.1 \%$ for low NDF:starch diet and 91.6\% for high NDF:starch diet). Intake of starch averaged $6.7 \mathrm{~kg} / \mathrm{d}$ and $5.5 \mathrm{~kg} / \mathrm{d}$ for the low and high NDF:starch diets (data not shown), but in an analysis of published data, Reynolds et al. (1997) showed that intake of starch (range was from about 4 to $11 \mathrm{~kg} / \mathrm{d}$ ) had no effect on starch digestibility by dairy cows. In another analysis of published data, Firkins et al. (2001) reported that, on average, starch digestibility decreased approximately 0.6 percentage units for every 1 percentage unit increase in the concentration of dietary NDF. In the present study, starch digestibility increased slightly with increasing dietary NDF concentration. As byproducts replaced corn grain (i.e., increasing NDF:starch ratio), the proportion of total dietary starch provided by corn silage increased from 28 to $37 \%$ with a concomitant decrease in the proportion of dietary starch provided by corn grain. The change in starch source may have had an effect on starch digestibility.

Digestibility of NDF was not different across diets (Table 3). Digestibility of fiber by dairy cows often decreases when starchy concentrates replace forage, but DMI can also increase (Putnam and Loosli, 1959; Valadares et al., 2000). In the present study, DMI as a percentage of BW tended to decrease $(P<0.10)$ as starch concentration increased. Digestibility of NDF often increases when starchy feeds are replaced by fibrous byproducts such as soyhulls (Edionwe and Owen, 1989; Cunningham et al., 1993). These results are confounded by changes in source of NDF (i.e., increased proportion 
Table 4. Effect of dietary NDF:starch ratios on utilization of dietary N.

\begin{tabular}{|c|c|c|c|c|c|c|}
\hline & \multicolumn{3}{|c|}{ Diets (NDF:starch) ${ }^{1}$} & \multirow[b]{2}{*}{ SEM } & \multicolumn{2}{|c|}{$P$ value $^{2}$} \\
\hline & 0.74 & 0.95 & 1.27 & & Linear & Quadratic \\
\hline MUN, mg/dL & 15.5 & 15.5 & 17.4 & 0.94 & 0.03 & 0.15 \\
\hline $\mathrm{N}$ intake, $\mathrm{g} / \mathrm{d}$ & 543 & 578 & 609 & 29 & 0.05 & NS \\
\hline Fecal N, g/d & 157 & 178 & 180 & 11 & 0.16 & NS \\
\hline Urinary $\mathrm{N}, \mathrm{g} / \mathrm{d}$ & 195 & 198 & 211 & 12 & 0.17 & NS \\
\hline Milk N, g/d & 176 & 173 & 173 & 10 & NS & NS \\
\hline $\mathrm{N}$ retention, $\mathrm{g} / \mathrm{d}$ & 15 & 29 & 45 & 12 & 0.03 & NS \\
\hline Productive N, ${ }^{3} \mathrm{~g} / \mathrm{d}$ & 191 & 202 & 218 & 15 & 0.06 & NS \\
\hline \multicolumn{7}{|l|}{$\%$ of $\mathrm{N}$ intake } \\
\hline Fecal N & 28.8 & 30.7 & 29.5 & 1.3 & NS & NS \\
\hline Urinary $\mathrm{N}$ & 36.0 & 34.3 & 34.8 & 1.6 & NS & NS \\
\hline Milk N & 32.8 & 30.1 & 28.5 & 1.4 & 0.01 & NS \\
\hline $\mathrm{N}$ retention & 2.3 & 4.8 & 7.1 & 1.9 & 0.02 & NS \\
\hline Productive N & 35.1 & 35.0 & 35.7 & 1.5 & NS & NS \\
\hline
\end{tabular}

${ }^{1}$ The NDF:starch ratio was altered by replacing corn grain with increasing amounts of a mixture of $54 \%$ soyhulls and $46 \%$ cottonseed hulls.

${ }^{2} \mathrm{NS}=P>0.20$.

${ }^{3}$ Productive $\mathrm{N}=\mathrm{N}$ excreted in milk plus $\mathrm{N}$ apparently retained by the cow.

of NDF supplied by soyhulls). The in situ and in vitro digestibility of NDF from soyhulls is higher than that of many other feeds (Ipharraguerre and Clark, 2003). In this experiment, the NDF that replaced starch had equal ISNDFD to the NDF in the corn silage. These data suggest that decreasing NDF:starch ratios from 1.24 to 0.74 does not affect NDF digestibility of corn silage-based diets when confounding factors are reduced. Alternate reasons for a lack of response in NDF digestibility to diet include compensatory NDF digestion in the hindgut, and inadequate differences among diets in carbohydrate fractions (i.e., all diets inhibited NDF digestion or no diet inhibited NDF digestion).

\section{Nitrogen Metabolism}

Intake of $\mathrm{N}$ increased linearly $(P<0.05)$ as the NDF:starch ratio increased (Table 4). This was a result of a trend toward higher DMI and an unexpected difference in $\mathrm{CP}$ concentration of diets. The amount of $\mathrm{N}(\mathrm{g} /$ d) in feces, urine, and milk was not affected by treatment, but apparent retention of $\mathrm{N}$ increased linearly $(P<0.03)$ as NDF:starch ratio increased. As a percentage of $\mathrm{N}$ intake, milk $\mathrm{N}$ decreased linearly and apparent retention of $\mathrm{N}$ increased linearly as the NDF:starch ratio increased. The concentration of MUN increased linearly $(P<0.03)$ as the NDF:starch ratio increased.

Table 5. Effect of dietary NDF:starch ratio on average (sampled immediately before feeding and at 3,6 , and $9 \mathrm{~h}$ postfeeding) rumen $\mathrm{pH}, \mathrm{VFA}$, and in situ NDF digestibility. ${ }^{1}$

\begin{tabular}{|c|c|c|c|c|c|c|}
\hline & \multicolumn{3}{|c|}{ Diets (NDF:starch) ${ }^{2}$} & \multirow[b]{2}{*}{ SEM } & \multicolumn{2}{|c|}{$P$ value ${ }^{3}$} \\
\hline & 0.74 & 0.95 & 1.27 & & Linear & Quadratic \\
\hline Mean $\mathrm{pH}$ & 5.73 & 5.84 & 5.79 & 0.09 & NS & 0.17 \\
\hline Total VFA, mM & 105.8 & 95.0 & 96.5 & 4.5 & 0.02 & 0.02 \\
\hline Acetate, $\mathrm{mol} / 100 \mathrm{~mol}$ of total VFA & 54.8 & 57.3 & 57.1 & 1.5 & 0.08 & 0.12 \\
\hline Propionate, $\mathrm{mol} / 100 \mathrm{~mol}$ of total VFA & 27.8 & 24.0 & 24.9 & 2.3 & 0.15 & 0.09 \\
\hline Butyrate, $\mathrm{mol} / 100 \mathrm{~mol}$ of total VFA & 12.4 & 14.4 & 13.8 & 1.3 & 0.16 & 0.07 \\
\hline Valerate, $\mathrm{mol} / 100 \mathrm{~mol}$ of total VFA & 3.6 & 2.5 & 2.3 & 0.5 & 0.02 & NS \\
\hline Acetate:propionate & 2.06 & 2.47 & 2.39 & 0.2 & 0.11 & 0.08 \\
\hline $\begin{array}{l}30 \text {-h in situ NDF digestibility, }{ }^{4} \% \\
\text { Corn silage }\end{array}$ & 32.5 & 32.7 & 37.7 & 4.0 & NS & NS \\
\hline Concentrate & 55.0 & 46.3 & 49.3 & 4.4 & NS & NS \\
\hline TMR & 38.9 & 38.7 & 45.1 & 3.9 & NS & NS \\
\hline
\end{tabular}

\footnotetext{
${ }^{1}$ No sampling time $\times$ diet interactions were observed $(P>0.20)$.

${ }^{2}$ The NDF:starch ratio was altered by replacing corn grain with increasing amounts of a mixture of $54 \%$ soyhulls and $46 \%$ cottonseed hulls.

${ }^{3} \mathrm{NS}=P>0.20$.

${ }^{4}$ The same corn silage was incubated in all cows, but the concentrate and TMR samples were incubated only in cows fed the respective concentrate and TMR.
} 


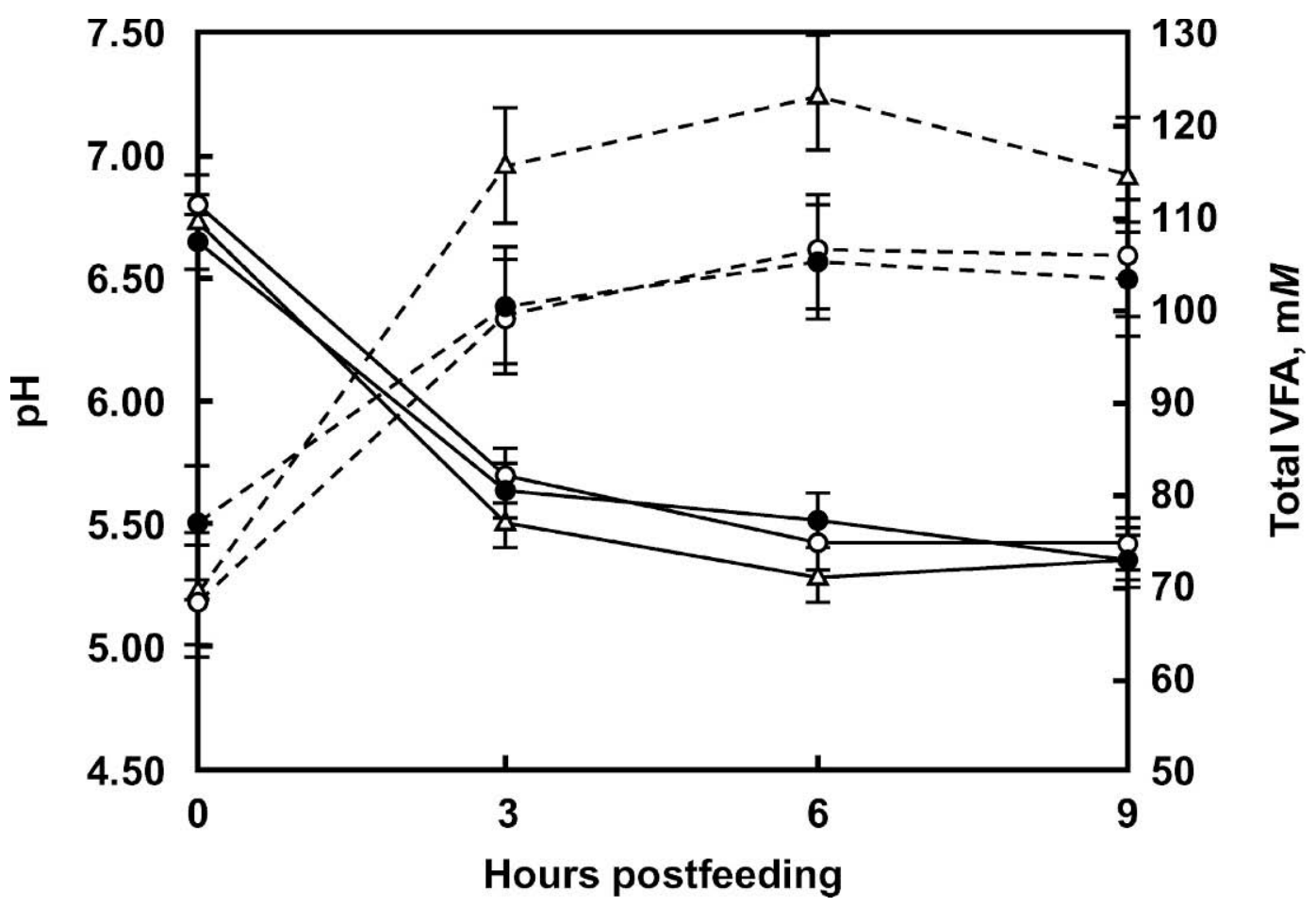

Figure 1. Total ruminal VFA concentration (dashed lines) and $\mathrm{pH}$ (solid lines) for cows fed diets with NDF:starch ratios of $0.74(\triangle)$ ), $0.95(\mathrm{O})$, and $1.27(\bullet)$. Vertical lines represent SEM. The 0-h sample was collected immediately before feeding.

This effect could be caused by differences in concentration and intake of $\mathrm{CP}$, changes in carbohydrates, or both. When dietary NDF:starch ratios were increased by replacing high moisture corn with alfalfa silage (other changes were also made in CP sources), MUN increased (Valadares et al., 2000), but when the ratio was altered by replacing corn with soyhulls, MUN was not affected (Kauffman and St-Pierre, 2001). Kononoff and Heinrichs (2003) reported increased MUN when cottonseed hulls replaced corn silage (diets had approximately equal NDF:starch ratios based on estimated starch concentrations). When treatment was removed from the statistical model and MUN was included as a continuous variable, MUN had a strong positive $(P<$ 0.001 ) relationship with urinary excretion of $\mathrm{N}$ confirming the value of MUN to estimate urinary N (Kauffman and St-Pierre, 2001; Kohn et al., 2002).

\section{Rumen Measures}

Time of sampling affected all variables $(P<0.01)$ but no time by diet interactions were observed $(P>0.20)$. For most rumen measures, differences appeared larger between the diet with NDF:starch ratio of 0.74 and the other 2 diets (i.e., quadratic effect). The mean concentration of total VFA decreased linearly $(P<0.02)$ and quadratically $(P<0.02)$ as the NDF:starch ratio in- creased but mean $\mathrm{pH}$ was not affected by diet (Table 5 ; Figure 1). The change in VFA concentration probably reflects increased ruminal fermentability as starch replaced NDF (Sutton et al., 1987). Average ruminal pH (5.79) was not affected by diet and was relatively low, but because of the sampling schedule, the mean does not represent a daily mean. Increasing NFC can decrease ruminal pH (Sievert and Shaver, 1993) but can also have no effect (Robinson et al., 1986). Rumen pH represents the net balance between carbohydrate digestion (i.e., acid production), VFA absorption and use, and buffer production. Although Allen (1997) found a negative correlation between ruminal $\mathrm{pH}$ and VFA concentration, the relationship was weak $\left(\mathrm{r}^{2}=0.13\right)$, probably because so many other factors contribute to ruminal $\mathrm{pH}$.

Molar proportions of VFA either tended to $(P<0.10)$ or were affected $(P<0.05)$ by treatment (Table 5$)$. The molar proportions of acetate (linear) and butyrate (quadratic) increased and propionate (quadratically) and valerate (linearly) decreased with increasing $\mathrm{NDF}$ :starch ratios. The acetate to propionate ratio increased quadratically with increasing NDF:starch ratios. The observed changes in the VFA profile are consistent with previous responses when dietary starch (or NFC) was increased at the expense of fiber (Robinson et al., 1986; Reynolds et al., 1997). 
Table 6. Effect of dietary NDF:starch ratio on DMI, milk production, and milk composition measured during the last 2 wk of each period.

\begin{tabular}{|c|c|c|c|c|c|c|}
\hline & \multicolumn{3}{|c|}{ Diets (NDF:starch) ${ }^{1}$} & \multirow[b]{2}{*}{ SEM } & \multicolumn{2}{|c|}{$P$ value ${ }^{2}$} \\
\hline & 0.74 & 0.95 & 1.27 & & Linear & Quadratic \\
\hline DMI, kg/d & 20.3 & 21.0 & 21.7 & 0.99 & 0.13 & NS \\
\hline DMI, $\%$ of BW & 3.26 & 3.34 & 3.50 & 0.19 & 0.10 & NS \\
\hline Milk, kg/d & 32.3 & 31.7 & 31.6 & 2.00 & NS & NS \\
\hline $\mathrm{ECM}^{3}{ }^{3} \mathrm{~kg} / \mathrm{d}$ & 33.5 & 34.8 & 34.8 & 2.63 & NS & NS \\
\hline Milk fat, $\%$ & 3.63 & 4.09 & 4.12 & 0.36 & 0.05 & NS \\
\hline Milk fat, $\mathrm{kg} / \mathrm{d}$ & 1.17 & 1.29 & 1.30 & 0.15 & NS & NS \\
\hline Milk protein, \% & 3.35 & 3.36 & 3.36 & 0.10 & NS & NS \\
\hline Milk protein, $\mathrm{kg} / \mathrm{d}$ & 1.08 & 1.06 & 1.06 & 0.06 & NS & NS \\
\hline $\mathrm{ECM} / \mathrm{DMI}$ & 1.65 & 1.65 & 1.60 & 0.07 & NS & NS \\
\hline BW, kg & 630 & 628 & 627 & 13.2 & NS & NS \\
\hline BW change, $\mathrm{kg} / \mathrm{d}$ & 0.03 & 0.00 & 0.02 & 0.02 & NS & NS \\
\hline
\end{tabular}

${ }^{1}$ The NDF:starch ratio was altered by replacing corn grain with increasing amounts of a mixture of $54 \%$ soyhulls and $46 \%$ cottonseed hulls.

${ }^{2} \mathrm{NS}=P>0.20$.

${ }^{3} \mathrm{ECM}=$ Energy-corrected milk (Tyrrell and Reid, 1965).

Diet had no effect on 30-h ISNDFD of the corn silage, concentrates, or TMR. The corn silage was a common substrate among cows and any diet effect would have been caused by changes in ruminal environment. The concentrate and TMR were different and any diet effects would reflect changes in ruminal environment and differences in substrate. The substrates were incubated at the same time as the in vivo digestion trial was conducted and in the same cows. The lack of diet effects on ISNDFD agrees with the lack of effects on in vivo NDF digestibility, however, ISNDFD for the TMR (average for diets $=40.9 \%)$ was lower $(P<0.05)$ than in vivo digestibility (average $=46.0 \%$ ), but no diet $\times$ method interaction was observed $(P>0.20)$. In vivo NDF digestibility should differ from ISNDFD for several reasons. The ISNDFD was measured at $30 \mathrm{~h}$ but actual retention time in vivo was not known. Based on passage rate calculated using NRC (2001), average ruminal turnover time of feeds was about $20 \mathrm{~h}$ for cows in this experiment. In lactating dairy cows, an average of $88 \%$ of total tract NDF digestion occurs in the rumen [calculated from the data collated by Firkins et al. (2001)]. In this experiment, the average ISNDFD for the TMR was $89 \%$ of the average in vivo NDF digestibility. The microenvironment ( $\mathrm{pH}$, microbial population, etc.) in the bag may differ from the environment in the rumen (Marinucci et al., 1992), and samples in in situ bags are ground before incubation and are not ruminated.

\section{Production Measures}

Other than a linear trend $(P<0.10)$ of increasing DMI (as \% of BW) and a linear increase in milk fat percentage as dietary NDF:starch increased, production measures were not affected by diet (Table 6). The linear trend of increased DMI as NDF:starch ratios increased is likely a real effect because the statistical power of this experiment was limited for detecting treatment effects on production measures. In contrast, many studies found reduced DMI when NDF is increased (Beauchemin and Buchanan-Smith, 1989; Canale et al., 1990). In a review, Allen (2000) found DMI to be negatively correlated with forage content and dietary NDF concentration. However, replacing grain with byproducts did not appear to have a consistent effect on DMI (Allen, 2000).

Increased milk fat percentage is commonly observed when NDF concentrations are increased at the expense of starch (Beauchemin and Buchanan-Smith, 1989; Batajoo and Shaver, 1994). The relationship between changes in ruminal acetate:propionate (Table 5) and change in milk fat percentage (Table 6) is similar to that derived by Erdman (1988) from literature data. Milk protein concentration and yield were not affected by diet, although others (Batajoo and Shaver, 1994; Valadares et al., 2000) have reported increased protein concentration or yield as grain replaced forage or fibrous byproducts (i.e., decreased the NDF:starch ratio). However, in those studies DMI, and based on DM digestibility, DE intake also increased as starch replaced fiber. Emery (1978) concluded that energy intake, rather than changes in fiber concentration, was primarily responsible for increased milk protein concentrations or yield. In our study, intake of DE was not affected by treatment (Table 7), therefore a lack of a diet effect on milk protein was not unexpected. If increased NDF:starch ratios resulted in decreased DMI and DE intake (e.g., if low quality forages replaced corn grain) production responses would likely have differed. 
Table 7. Effect of altering dietary NDF:starch ratios on measures of energy utilization and comparison of different methods of obtaining digestible energy (DE) concentrations and $\mathrm{NE}_{\mathrm{L}}$ balance.

\begin{tabular}{|c|c|c|c|c|c|c|}
\hline \multirow[b]{2}{*}{ Item $^{1}$} & \multicolumn{3}{|c|}{ Diets (NDF:starch) ${ }^{2}$} & \multirow[b]{2}{*}{ SEM } & \multicolumn{2}{|c|}{$P$ value ${ }^{3}$} \\
\hline & 0.74 & 0.95 & 1.27 & & Linear & Quadratic \\
\hline $\mathrm{NE}_{\mathrm{L}}$ use, $\mathrm{Mcal} / \mathrm{d}$ & 33.1 & 34.0 & 34.0 & 1.8 & NS & NS \\
\hline $\mathrm{NE}_{\mathrm{L}}$ intake, ${ }^{\mathrm{a}} \mathrm{Mcal} / \mathrm{d}$ & 34.4 & 34.6 & 35.1 & 1.6 & NS & NS \\
\hline Measured DE intake, Mcal/d & 63.1 & 63.7 & 65.5 & 3.06 & NS & NS \\
\hline Measured DE, Mcal/kg & 3.17 & 3.10 & 3.06 & 0.05 & 0.04 & NS \\
\hline NRC DE, ${ }^{\mathrm{b}} \mathrm{Mcal} / \mathrm{kg}$ & 3.10 & 3.05 & 2.99 & 0.03 & 0.01 & NS \\
\hline IS-NRC DE, ${ }^{\mathrm{b}} \mathrm{Mcal} / \mathrm{kg}$ & 3.04 & 2.99 & 2.99 & 0.02 & 0.03 & 0.08 \\
\hline
\end{tabular}

${ }^{a} \mathrm{NE}_{\mathrm{L}}$ intake differed from NEL use for all diets $(P<0.05)$.

${ }^{b}$ Values differed from measured DE concentrations for all diets $(P<0.01)$.

${ }^{1} \mathrm{NE}_{\mathrm{L}}$ use was calculated by summing estimated (NRC, 2001) $\mathrm{NE}_{\mathrm{L}}$ used for maintenance, milk production, and $\mathrm{BW}$ change; $\mathrm{NE}_{\mathrm{L}}$ intake was calculated by multiplying $\mathrm{DMI}$ by estimated dietary $\mathrm{NE}_{\mathrm{L}}$ concentration (calculated using NRC (2001) equations with actual feed chemical composition data and DMI as inputs); NRC DE = DE calculated using NRC (2001) equations with actual feed chemical composition and DMI as inputs; IS-NRC DE = NRC DE except that measured in situ NDF digestibility was used for corn silage, soyhulls, and cottonseed hulls. Measured DE was calculated from measured digestibility of energy.

${ }^{2}$ The NDF:starch ratio was altered by replacing corn grain with increasing amounts of a mixture of $54 \%$ soyhulls and $46 \%$ cottonseed hulls.

${ }^{3} \mathrm{NS}=P>0.20$.

\section{Energy}

Calculated (NRC, 2001) energy expenditures for maintenance, milk production, and BW change averaged 33.4 Mcal of $\mathrm{NE}_{\mathrm{L}} / \mathrm{d}$ and was not affected by diet in agreement with the lack of diet effect on intake of $\mathrm{DE}$ (Table 7). Intake of $\mathrm{NE}_{\mathrm{L}}\left(\mathrm{DMI} \times\right.$ dietary $\mathrm{NE}_{\mathrm{L}}$ concentration calculated using the NRC model with chemical composition data and actual DMI as inputs) was not affected by diet, but estimated $\mathrm{NE}_{\mathrm{L}}$ intake was $3 \%$ higher $(P<0.05)$ than estimated $\mathrm{NE}_{\mathrm{L}}$ expenditures. If the $\mathrm{NE}_{\mathrm{L}}$ system is correct, $\mathrm{NE}_{\mathrm{L}}$ expenditures should equal $\mathrm{NE}_{\mathrm{L}}$ intake. The measured $\mathrm{DE}$ concentration of the diets (Table 7) decreased linearly from 3.17 to 3.06 $\mathrm{Mcal} / \mathrm{kg}(P<0.04)$ as NDF:starch ratio increased, reflecting the linear decrease in energy digestibility (Table 3). The concentration of dietary DE was also calculated using the NRC model based on actual DMI of each cow and chemical composition data (i.e., the calculated value includes the discount factor). Treatments had the same linear effect on estimated DE concentrations as they had on measured DE concentrations, however mean estimated DE was $2 \%$ lower $(P<0.01)$ than the mean measured DE (Table 7). When measured ISNDFD for cottonseed hulls, soyhulls, and corn silage were used in the NRC model, estimated DE concentrations decreased linearly with increasing NDF:starch ratio, but estimated values were on average $4 \%$ lower $(P<0.01)$ than measured values. The use of 30 -h ISNDFD was less accurate for estimating $\mathrm{DE}$ than was the use of chemical composition data. However, if the ISNDFD values were divided by 0.88 to account for possible postruminal NDF digestion, estimated DE values would be as accurate as values calculated from chemical composition data.

\section{CONCLUSIONS}

Increasing the NDF:starch ratio of diets by replacing corn grain with a mixture of byproducts linearly reduced digestibility of energy and DE concentrations. Increased DMI appeared to compensate for reduced DE concentrations so that intake of DE was similar among treatments. However, diet did not affect NDF digestibility when ISNDFD of the major NDF sources were similar even though one diet had NFC concentrations far in excess of NRC (2001) recommendations. Milk fat percentage increased as the NDF:starch ratio increased, which was consistent with the observed changes in the VFA profile of the rumen fluid. The DE concentrations of the diets estimated using chemical composition data and the NRC (2001) model also decreased linearly with increasing NDF:starch ratios but estimated values were about $2 \%$ lower than measured values. The use of in situ NDF digestibility did not improve the accuracy of the NRC model for estimating DE concentrations.

\section{REFERENCES}

Allen, M. S. 1997. Relationship between fermentation acid production in the rumen and the requirement for physically effective fiber. J. Dairy Sci. 80:1447-1462.

Allen, M. S. 2000. Effects of diet on short-term regulation of feed intake by lactating dairy cows. J. Dairy Sci. 83:1598-1624.

Armentano, L., and M. Pereira. 1997. Measuring the effectiveness of fiber by animal response trials. J. Dairy Sci. 80:1416-1425. 
Association of Official Analytical Chemists. 1990. Official Methods of Analysis. Vol. 1. 15th ed. AOAC, Arlington, VA.

Bannink, A., H. Valk, and A. M. van Vuuren. 1999. Intake and excretion of sodium, potassium, and nitrogen and the effects on urine production by lactating dairy cows. J. Dairy Sci. 82:1008-1018.

Batajoo, K. K., and R. D. Shaver. 1994. Impact of nonfiber carbohydrate on intake, digestion, and milk production by dairy cows. J. Dairy Sci. 77:1580-1588.

Beauchemin, K. A., and J. G. Buchanan-Smith. 1989. Effects of dietary neutral detergent fiber concentration and supplementary long hay on chewing activities and milk production of dairy cows. J. Dairy Sci. 72:2288-2300.

Canale, C. J., P. L. Burgess, L. D. Muller, and G. A. Varga. 1990. Calcium salts of fatty acids in diets that differ in neutral detergent fiber: Effect on lactation performance and nutrient digestibility. J. Dairy Sci. 73:1031-1038.

Colucci, P. E., G. K. Macleod, W. L. Grovum, L. W. Cahill, and I. McMillan. 1989. Comparative digestion in sheep and cattle fed different forage to concentrate ratios at high and low intakes. J. Dairy Sci. 72:1774-1785.

Cunningham, K. D., M. J. Cecava, and T. R. Johnson. 1993. Nutrient digestion, nitrogen, and amino acid flows in lactating cows fed soybean hulls in place of forage or concentrate. J. Dairy Sci. 76:3523-3535

Edionwe, A. O., and F. G. Owen. 1989. Relation of intake to digestibility of diets containing soyhulls and distillers dried grains. J. Dairy Sci. 72:1786-1792.

Emery, R. S. 1978. Feeding for increased milk protein. J. Dairy Sci. $61: 825-828$

Erdman, R. A. 1988. Dietary buffering requirements of the lactating dairy cow: A review. J. Dairy Sci. 71:3246-3266.

Firkins, J. L., M. L. Eastridge, N. R. St-Pierre, and S. M. Noftsger. 2001. Effects of grain variability and processing on starch utilization by lactating dairy cows. J. Anim. Sci. 79(Suppl E):E218E238.

Ipharraguerre, I. R., and J. H. Clark. 2003. Soyhulls as an alternative feed for lactating dairy cows: A review. J. Dairy Sci. 86:1052-1073.

Kauffman, A. J., and N. R. St-Pierre. 2001. The relationship of milk urea nitrogen to urine nitrogen excretion in Holstein and Jersey cows. J. Dairy Sci. 84:2284-2294.

Kohn, R. A., K. F. Kalscheur, and E. Russek-Cohen. 2002. Evaluation of models to estimate urinary nitrogen and expected milk urea nitrogen. J. Dairy Sci. 85:227-233.

Kononoff, P. J., and A. J. Heinrichs. 2003. The effect of corn silage particle size and cottonseed hulls in early lactation. J. Dairy Sci. $86: 2438-2451$

Llano, C. A., and E. J. DePeters. 1985. Apparent digestibilities of diets varying in ratios of forage to concentrate and quality of forage at two intakes by dairy cows. J. Dairy Sci. 68:1189-1197.

Marinucci, T. M., B. A. Dehority, and S. C. Loerch. 1992. In vitro and in vivo studies of factors affecting digestion of feeds in synthetic fiber bags. J. Anim. Sci. 70:296-307.
National Research Council. 2001. Nutrient Requirements of Dairy Cattle. 7th rev. ed. Natl. Acad. Press, Washington, DC

Putnam, P. A., and J. K. Loosli. 1959. Effect of feeding different ratios of roughage to concentrate upon milk production and digestibility of the ration. J. Dairy Sci. 42:1070-1078.

Reynolds, C. K., J. D. Sutton, and D. E. Beever. 1997. Effects of feeding starch to dairy cattle on nutrient availability and production. Pages 105-134 in Recent Advances in Animal Nutrition. P.C. Garnsworthy and J. Wiseman, ed. Nottingham Univ. Press, Nottingham, UK.

Robertson, J. B., and P. J. Van Soest. 1981. The detergent system of analysis and its application to human foods. Pages 123-158 in The Analysis of Dietary Fiber in Food. W. P. T. James and O. Theander, ed., Marcel Dekker, Inc., New York, NY.

Robinson, P. H., S. Tamminga, and A. M. van Vuuren. 1986. Influence of declining level of feed intake and varying the proportion of starch in the concentrate on rumen fermentation in dairy cows. Livest. Prod. Sci. 15:173-189.

SAS Institute. 1999. SAS/STAT User's Guide, Version 8. SAS Institute Inc., Cary, NC.

Sievert, S. J., and R. D. Shaver. 1993. Effect of nonfiber carbohydrate level and Aspergillus oryzae fermentation extract on intake, digestion, and milk production in lactating dairy cows. J. Anim. Sci. 71:1032-1040.

Sutton, J. D., J. A. Bines, S. V. Morant, D. J. Napper, and D. I. Givens. 1987. A comparison of starchy and fibrous concentrates for milk production, energy utilization and hay intake by Friesian cows. J. Agric. Sci. (Camb.) 109:375-386.

Tine, M. A., K. R. McLeod, R. A. Erdman, and R. L. Baldwin, VI. 2001. Effects of brown midrib corn silage on the energy balance of dairy cattle. J. Dairy Sci. 84:885-895.

Tyrrell, H. F., and P. W. Moe. 1972. Net energy value for lactation of a high and low concentrate ration containing corn silage. J. Dairy Sci. 55:1106-1112.

Tyrrell, H. F., and P. W. Moe. 1975. Effect of intake on digestive efficiency. J. Dairy Sci. 58:1151-1163.

Tyrrell, H. F., and J. T. Reid. 1965. Prediction of the energy value of cow's milk. J. Dairy Sci. 48:1215-1223.

Valadares, S. C., G. A. Broderick, R. F. D. Valadares, and M. K. Clayton. 2000. Effect of replacing alfalfa silage with high moisture corn on nutrient utilization and milk production. J. Dairy Sci. 83:106-114

Weiss, W. P. 2004. Factors affecting manure excretion by dairy cows. Pages 11-20 in Proc. Cornell Nutr. Conf., Syracuse, NY. Cornel Univ., Ithaca, NY.

Weiss, W. P., and W. L. Shockey. 1991. Value of orchardgrass and alfalfa silages fed with varying amounts of concentrates to dairy cows. J. Dairy Sci. 74:1933-1943.

Weiss, W. P., and D. J. Wyatt. 2000. Effect of oil content and kernel processing of corn silage on digestibility and milk production by dairy cows. J. Dairy Sci. 83:351-358. 